\section{In search of memory}

The emergence of a new science of mind

Eric R. Kandel

W.W. Norton \& Company. New York, New York, USA. 2006.

352 pp. \$29.95. ISBN: 0-393-05863-8 (hardcover).

Reviewed by Andrew R. Marks

Columbia University, New York, New York, USA.

E-mail:arm42@columbia.edu

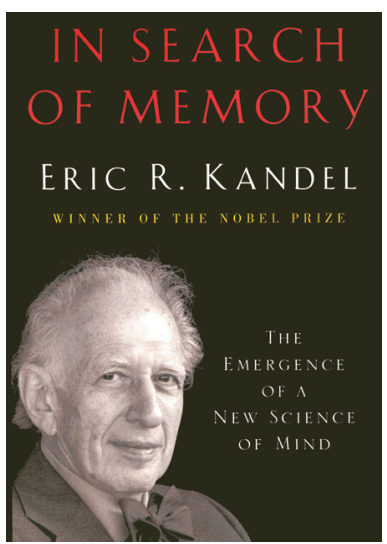

W hat was life like growing up Jewish in Nazi-controlled Vienna? How does your brain form and retain memories, and who are the giants in neuroscience whose work unraveled these mysteries? What does it feel like to win a Nobel Prize? Answers to these seemingly disparate questions are found in In search of memory: the emergence of a new science of mind by Eric Kandel. Kandel has masterfully woven diverse themes into a beautiful tapestry that at once provides insight into his own remarkable life and career as a neuroscientist and illustrates the modern field of neuroscience in language that the nonexpert can appreciate. Kandel provides compelling reasons to believe that we can emerge from the horrors of our past by letting ourselves explore the mysteries of humanity as exemplified by his own experiences.

Unlike most general interest books by scientists, In search of memory is crisp, clear, and compelling. Those who know the incredible dexterity of Kandel's mind appreciate that each nuance in his tale is the product of careful analysis; nothing has been left to chance. The book begins with his early memories growing up in Vienna - such as the knock on the door of his family's apartment when the Nazi soldiers came to take him and his family. His message is clear: this is a book about memory shaped by very personal experiences.

Indeed, there is a satisfying and upbeat symmetry to Kandel's tale, which opens with Nazis knocking on his door but ends with an equally startling yet profoundly more hopeful phone call, coincidentally on Yom Kippur, announcing that he has been awarded a Nobel Prize.

Kandel speculates on how the trauma of his early experiences in Vienna altered his life. He recounts witnessing hundreds of thousands of Viennese pour out on the streets to celebrate Hitler's triumphant march into Vienna and the subsequent humiliation of the Viennese Jews. "It is difficult to trace the complex interests and actions of one's adult life to specific experiences in childhood and youth," Kandel writes. He provides no answers to this speculation other than to say that if he were "to start anew" he might study the "biological component of our unconscious mental life." No doubt some future reader of his book will address this profound problem.

$\mathrm{He}$ is particularly diligent in honoring those who laid the foundations of modern biological sciences. Kandel - a brilliant scientist whose writing is equal to that of the best historians - reports, interprets, and helps us appreciate the context and significance of each major scientific milestone.

Kandel explains the intellectual basis for his choice of a model organism, the sea snail Aplysia, which he used to elucidate fundamental principles of how memories are formed and stored in the brain. This work led to his sharing the 2000 Nobel Prize for Medicine or Physiology with Avrid Carlsson and Paul Greengard. He describes the reduction of the elusive concept of memory to a biology based on specific proteins and chemicals. These are tangible signals that can be measured and are conserved evolutionarily, thus allowing Kandel and colleagues to understand how the brains of advanced organisms work by studying those of more primitive ones. His tenacity and passion for science provide a model for the pursuit of a career in research that all young scientists should study.
In addition, Kandel has carefully examined the history of Vienna and its attitude toward Jews. His insights are unique, coming from the perspective of a Jewish intellectual who remains attracted to the cultural ideals of pre-Nazi Vienna. He is not a rabid Zionist, and his perspective is distinct from other Holocaust survivors, in part because, thankfully, Kandel's family never experienced the concentration camps. Memories of a year living under Nazi rule before his family escaped to the United States come to life in Kandel's book. His exploration of Austria's past and current anti-Semitism and subsequent failure to examine its role in the Holocaust, in contrast to the soul searching undertaken by Germany, are an insightful and extremely important contribution to the dialogue on this topic.

Kandel's verbal style comes through clearly in his writing, and we see from whence his humor comes: "My father, Hermann Kandel - to whom my mother was immediately attracted because she found him handsome, energetic, and filled with humor ...." Joy with his life in science, sometimes painful exploration of his own roots in Judaism and his childhood in Vienna, his love of family, and the burning curiosity that continues to drive him are readily conveyed through the pages of this book.

The only shortcoming of this important book is that it is not accompanied by a DVD containing Kandel's lectures. At Columbia we delight in appreciating Eric Kandel in person. For the rest of the world, his book is the closest one can come to this rich intellectual experience - don't miss it! Indeed, Kandel's book promises to do for neuroscience what The double belix has done for DNA. 